\title{
Makeup as a process of social-emotional development
}

\section{Maquillaje como proceso de desarrollo socio-emocional}

\author{
RAMOS-JAUBERT, Rocío Isabel†*, MUÑOZ- LÓPEZ, Temístocles, GONZÁLEZ- CEPEDA, María \\ Cristina and NAVARRO- AGUILAR, Verónica Raquel
}

Universidad Autónoma de Coahuila. Facultad de Ciencia, Educación y Humanidades. Saltillo, Coah. Universidad Autónoma de Coahuila. Escuela de Sistemas "Marcial Ruiz Vargas". Ciudad Acuña, Coah.

ID $1^{\text {st }}$ Author: Rocío Isabel, Ramos-Jaubert / ORC ID: 0000-0003-3289-5390, Researcher ID Thomson: T-1652-2018, CVU CONACYT ID: 201861

ID $1^{\text {st }}$ Coauthor: Temístocles, Muñoz- López / ORC ID: 0000-0003-4940-5730, Researcher ID Thomson: X-7834-2018; CVU CONACYT ID: 202437

ID $2^{\text {nd }}$ Coauthor: María Cristina, González- Cepeda / ORC ID: 0000-0003-0676-2412, Researcher ID Thomson: T-16512018, CVU CONACYT ID: 567204

ID $3^{\text {rd }}$ Coauthor: Verónica Raquel, Navarro- Aguilar

DOI: $10.35429 /$ EJC.2020.10.6.1.5

Received April 08, 2020; Accepted June 30, 2020

\begin{abstract}
The objective is to know the educational process of socioemotional development in the construction of personality, which is extremely important today, since educational models revolve around this axis. In the world, approximately 74,200 million dollars were spent in 2019, in Mexico in 2019 it could exceed 154,000 million pesos. A qualitative ethnomethodological research was carried out with 100 higher education students, men and women, period April-June 2019. The data was collected through a survey / interview with an instrument of 123 questions. The different students of the subject processes related to the importance of studying the educational ones in the socio-emotional development as part of the personality through the use of makeup, recognizing that there is a lack of information in this area. Women use cosmetic products to show in a physical way how they feel, whether it is sophisticated, elegant, daring or calm with natural makeup. The project contributes to future lines of research to delve into the abuse and exaggerated use of makeup and its relationship with deception, lies and control that creates dependence on products such as neon shadows, false eyelashes, highlighters and contour in everything the body.Keywords: Makeup, personality, socio-emotional development.
\end{abstract}

Makeup, Personality, Socio-emotional development

\begin{abstract}
Resumen
El objetivo es conocer el proceso educativo del desarrollo socioemocional en la construcción de la personalidad, lo cual es sumamente importante en la actualidad, pues los modelos educativos giran en torno a este eje. En el mundo se gastaron aproximadamente 74,200 millones de dólares en 2019, en México en el 2019 podría superar los 154,000 millones de pesos. Se realizó una investigación cualitativa etnometodológica con 100 estudiantes de educación superior, hombres y mujeres, periodo abril- junio 2019. Los datos se recolectaron a través de una encuesta/ entrevista con un instrumento de 123 preguntas. Los diferentes estudiosos del tema refieren la importancia de estudiar los procesos educativos en el desarrollo socioemocional como parte de la personalidad a través del uso del maquillaje, reconociendo que falta información en este rubro. Las mujeres utilizan los productos cosméticos para evidenciar de una forma física el cómo se sienten, ya sea sofisticada, elegante, atrevida o tranquila con un maquillaje natural. El proyecto contribuye en las futuras líneas de investigación para profundizar sobre el abuso y uso exagerado del maquillaje y su relación con el engaño, la mentira y el control que crea la dependencia de productos como las sombras neon, pestañas postizas, iluminadores y contour en todo el cuerpo.
\end{abstract}

Maquillaje, Personalidad, Socioemocional

Citation: RAMOS-JAUBERT, Rocío Isabel, MUÑOZ- LÓPEZ, Temístocles, GONZÁLEZ- CEPEDA, María Cristina and NAVARRO- AGUILAR, Verónica Raquel. Makeup as a process of social-emotional development. ECORFAN JournalRepublic of Colombia. 2020. 6-10: 1-5

\footnotetext{
* Correspondence to Author (email: rocio.ramos.jaubert@uadec.edu.mx)

$\dagger$ Researcher contributing as first author.
} 


\section{Introduction}

Throughout life, there are stages in which women look and feel different and it is not only because of the evolutionary process of growth, but because of cosmetic products and more for the cultural evolution with the increase of products and trends that come every season, there are many factors that make them sometimes seem like a different person, not only at sight but in their personality. One of these factors is makeup, even in daily use (Echenique, 2020; Juscamaita García, Garrido Barnuevo, \& De los Ríos Ramírez, 2020). One study mentions that a woman spends an estimated $\$ 15,000$ on cosmetic products over her lifetime where 3,700 dlls is just invested in mascara for eyelashes. So if they say that what matters is inner beauty, why does she take the time to put on makeup and look different?

The educational process of socialemotional development through makeup and its impact on personality is the line of research of this study. The importance that can be given to a product about oneself, to the point that one comes to consider more important than the aspects of personality is the description of the problem at a macro level is: Looking and feeling good are some of the most important things, but which is more important?

In particular and including the perspective of women and men that will make you understand how important it is. Knowing that with the increase in demand for products the cost of them increases, women decide to invest in them more than they should. The makeup is not a mask to hide behind, but it is an ability to stand out and favors self-esteem.

The added value lies in the description of the subjects and object of study. The object of study is to obtain information of the educational process of the social-emotional development in the personality of a woman through the makeup, the subjects will be 100 people who study superior education in the period of April to June of 2019 as much men as women, the theoretical relevance of the project is to obtain customized information of the educational process of the social-emotional development.
The methodological relevance aims at developing a survey/interview format, providing an instrument to know the population under study about the importance of make-up and personality and, the practical relevance aims at developing ways to obtain information about make-up and personality as an educational process of socio-emotional development, favouring the process of promoting personal autonomy and social inclusion of people (Mondragón, Abad Fernández \& Rodríguez Castrillón, 2020; Moreno Portillo, 2020).

\section{General objective:}

To know the educational process of socioemotional development of the personality through the use of make-up.

\section{Specific objective:}

Knowing elements of makeup that impact socialemotional development

\section{Theoretical Fundamentals}

Makeup is not something recent, however, its importance has increased over the years. Makeup is a mask, a defense, a wonderful weapon of deterrence against the time factor approaching the ideal of beauty of a given society, a way to escape from the sad contingencies of daily life, to surpass oneself and become another woman; it demonstrated social status, the dark complexion was related to days under the sun and the pale complexion meant high royalty (Rojas and Acevedo, 2015).

Used in different cultures, latitudes and altitudes of the planet since ancient Egypt, the Roman Empire, the Middle Ages, the seventeenth and eighteenth centuries, the nineteenth and twentieth centuries hiding imperfections, the use of makeup involves the acceptance and adaptation of the social circle to which one belongs or wishes to belong.

Knowing how makeup was previously perceived is important in order to recognize the meaning they gave to it and to compare them with the present day and how they are used. Makeup does not define a person, although it is a complement to their personality (Silva and Diaz, 2011; Siza, 2014). 
The origin of makeup derives from the Greek "kosmetikos" which means "skillful in decoration" and these have had a different purpose during the different times of history, as far as we know in ancient Egypt they made up to show hierarchy and today we see that every season changes something, for a product with better quality to achieve a "look" more dramatic or more serious.

Personality is an organization made up of all the cognitive, affective and evolutionary characteristics of an individual (Warner, Dictionary of Psychology). According to Jung, personality is the supreme realization of the innate idiosyncrasy of being (Stamateas, 2012). There are different definitions for personality according to the authors and the approach that each one handles, nevertheless, the dictionary of the Spanish language defines it as the "individual difference that constitutes each person and distinguishes it from another".

\section{Methodology}

This study is a qualitative research of ethnomethodological type, when reflecting on the social construction, based on the educational processes of the social-emotional development of the personality through the makeup Sampling was non-probability by intentionally selecting the study population based on explicit criteria. One hundred male and female higher education students participated.

\section{Inclusion criteria:}

Persons over 18 years of age (adults). Higher education students. Men and women.

\section{Exclusion criteria:}

Being under 18 years of age. Not to be students of higher education.

\section{Elimination criteria:}

Not wishing to participate in the study. Pass away, change universities.

The instrument developed is a survey/interview made up of 123 questions, 13 of which are signal data and 110 questions related to the subject of the study. It has an interval-type ratio scale -centesimal- where 0 is the absence of the attribute and 100 is the maximum value that the respondent can obtain. It was applied mainly in educational institutions with a humanities orientation.
The survey took between 25 and 45 minutes to answer. Requesting permission for the application of the same.

\section{Results}

The most important thing for a woman's makeup involves her personality and her presentation so she is confident and supports others by showing emotional stability and confidence. Because when she feels good she is happy, making decisions independently without losing her honesty, sincerity and love, because responsibility and kindness show selfsufficiency and fun. That with a positive attitude he is reliable, loyal and faithful.

The least important thing for a woman's makeup involves the use of neon shadows, false eyelashes, brown eyeliner, cateye liner, glitter, smokey eye and a lot of mascara on the eyes. For the lips the use of gloss, glitter, purple and brown lipstick as well as creating full lips. In a general concept of the face the contour and contour in the body with the use of natural or not brushes, the use of golden or dark illuminator and pink or red blush. So the use of certain products used to make up the woman shows a deception in its presentation until getting to seem another person, with a negative and controlling attitude. For the makeup of a woman who wants to look good in a natural way, daring, dominant, young, perverse, elegant and with prestige, where the products of common use are neutral shadows creating well defined eyes, black eyeliner, eyelash curler with the use of little mascara for natural eyelashes, red, pink and nude lipstick, matte type lipstick, primer, concealer, translucent powder, and beauty blender.

Whether a woman wears natural, defined eyebrows, lasts 5 minutes or 1 hour, wears mascara, creates emphasis on her eyes or tender lips, or even is not using any makeup, what stands out most in the social-emotional education of a woman's personality is feeling sophisticated, daring, and sociable, romantic, loving, creative, enthusiastic, logical, reserved, altruistic, leader, sympathetic, dominant, empathetic, idealistic, daring, tolerant, friendly, optimistic, innovative, charismatic, realistic, adventurous, competitive and passionate having control over herself and her life but at the same time becoming dependent on the use of make-up. Pearson's Product-Moment Correlations: 
It is shown that makeup allows a woman to feel good, happy and confident. It reveals her emotional stability, independence and love to present herself as a self-sufficient woman in order to make responsible decisions by being faithful and loyal to herself. Demonstrating to be a friendly and sympathetic person with a realistic and reliable perspective to different situations and the same by showing herself to be sincere and trustworthy to others.

A person with emotional stability is happy and independent to make decisions towards new adventures as a spiritual being receiving them with a positive and enthusiastic attitude. Having self-confidence as well as generating confidence by introducing herself, as well as being sociable and empathetic. Being sincere, honest and kind to others showing tolerance and charisma towards them with loyalty, love, fidelity and good friendship. Besides being someone creative and innovative, he has a realistic and responsible perspective on life by being optimistic in situations to feel good and love what he is doing. With the precaution of not looking like someone else.

It was discovered that makeup is part of the presentation of a woman to look young, elegant and daring. For this result it is required the dedication to make up 1 hour and be in control, since it is important to emphasize the eyes type smokey eye, with the use of false eyelashes and much mascara. As well as using black eyeliner to create a cat-eye line to show them in a more defined way. Using natural brushes, beauty blender, translucent powder, create contour on the face and use concealer to define the eyebrows. Without leaving aside the use of brown lipstick to create voluminous lips for the bold and elegant presentation of a woman.

Being happy goes beyond feeling good and having a positive attitude is shown to go hand in hand with kindness and sincerity by showing yourself to be someone trustworthy and honest to socialize and convey. By showing that you are an independent, emotionally stable person demonstrating love and loyalty to yourself. Making responsible decisions without giving up your spiritual and adventurous self.

\section{Acknowledgements}

We thank Dyslexia: Center for Neuropsychology for its financial support in the development of this research. Office 2019-09010 .

\section{Conclusions - contribution}

Women use cosmetic products to show in a physical way how they feel, whether it is sophisticated, elegant, daring or calm with a natural make-up. It was demonstrated that the influence of the products goes towards how the woman feels and how she wants to present herself for the different occasions of her life. This is a support to some extent emotional but does not change the personality of a woman completely or affect their decision making in perspective with or without the makeup. It is a letter of introduction to herself that is linked to her emotional well-being.

As an area of opportunity it is suggested to open a line of investigation about the abuse of the exaggerated use of makeup and its relationship with deception, lying and control that creates the dependence of such products as neon shadows, false eyelashes, illuminators and contour in the whole body.

The theoretical relevance of the project is to obtain personalized information of the educational process of the social-emotional development of the personality through the use of makeup, which was obtained when reaching the objective of the investigation; the methodological utility intends the development of a survey/interview format, providing an instrument to know the population under study about the importance of makeup and personality and how the educational process of the socialemotional development impacts; and the practical relevance aims to develop ways of obtaining information about makeup and personality as an educational process of socioemotional development, which is achieved by specifying how the different types of makeup favor it as a letter of introduction. 


\section{References}

Echenique Jiménez, E. (2020). Propuesta lúdico recreativa, pedagógica teatral, para potenciar la atención y la resiliencia en los estudiantes de grado décimo del liceo Guillermo Valencia de Montería. Los libertadores. Fundación Universitaria.

Juscamaita García, J. A., Garrido Barnuevo, Y. I., \& De los Ríos Ramírez, L. F. (2020). El entorno de aprendizaje favorece la producción de un programa televisivo como logro del taller. de televisión de los estudiantes del quinto ciclo de la carrera de Comunicación Audiovisual y Multimedia de un instituto de Lima Metropolitana, durante el periodo académico 2019-I. Universidad Tecnológica del Perú.

Mondragón, J. A., Abad Fernández, A., \& Rodríguez Castrillón, L. (2020). Diseño de talleres para el desarrollo personal y la inclusión social de las personas con DCA. Repositorio Iberoamericano sobre Discapacidad.

Moreno Portillo, L. C. (2020). Infancia, diversidad sensorial y derecho a la ciudad: una propuesta para considerar la danza como poética del habitar. Universidad Pedagógica Nacional de Colombia.

Rojas-Castillo, Z. M., \& Acevedo-Suárez, A. (2015). El alcance del derecho al libre desarrollo de la personalidad en manuales de convivencia de establecimientos educativos. Dixi, 17(21).

Silva, E. A., \& Díaz, D. M. (2011). Redes semánticas naturales: técnica para representar los significados que las jóvenes universitarias tienen del maquillaje. Cuadernos Latinoamericanos de Administración, 7(12), 6170.

Siza Flores, J. M. (2014). Estudio del comportamiento de compra al adquirir ropa y maquillaje del grupo GLBT en la ciudad de Quito (Bachelor's thesis, UNIVERSIDAD TECNOLOGICA EQUINOCCIAL. FACULTAD: CIENCIAS ECONÓMICAS Y NEGOCIOS).

Stamateas, A. (2012). Mujeres que brillan: Cómo desarrollar una personalidad atractiva. Grijalbo 